\title{
Enhanced Effluent Quality of Anaerobic Baffled Reactor (ABR) with Ozone and Aerobic Activated Sludge for Livestock Wastewater Treatment
}

\author{
Anshah Silmi Afifaha,*, Muhammad Rizki Apritama ${ }^{\mathrm{b}}$, Yosef Adicitac ${ }^{\mathrm{c}}$ I Wayan Koko Suryawan ${ }^{\mathrm{d}}$, \\ Iva Yenis Septiariva ${ }^{\mathrm{e}}$

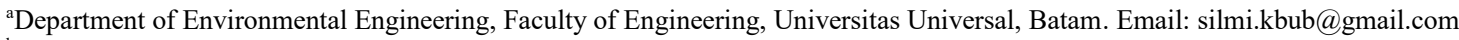 \\ bDepartment of Environmental Engineering, Faculty of Engineering, Universitas Universal, Batam. Email: rizkiapritama@outlook.com \\ 'Department of Environmental Engineering, Faculty of Engineering, Universitas Universal, Batam. Email: yoseph_cita@yahoo.com \\ ${ }^{\mathrm{d}}$ Department of Environmental Engineering, Faculty of Infrastructure Planning, Universitas Pertamina, Jakarta. \\ Email: i.suryawan@universitaspertamina.ac.id \\ eDepartment of Civil Engineering, Faculty of Engineering, Universitas Sebelas Maret, Kota Surakarta. Email: ivayenis@staff.uns.ac.id
}

\begin{abstract}
ABR used to treat wastewater with high COD level such as livestock wastewater. ABR treatment consists of compartments which are limited by vertical bulkhead growth with attached bacteria. However, ABR treatment only capable degraded COD level by $50-53 \%$. This value did not qualify to be discharged into the environment. Therefore, ABR treatment need further treatment with ozone treatment and aerobic activated sludge. There were two treatments in this study, which are ABR with ozone treatment and aerobic activated sludge (S1) and ABR with aerobic activated sludge (S2). COD degradation with ozone treatment showed low efficiency, $31.1 \pm 1.5 \%$ but BOD/COD level increased. Aerobic activated sludge with batch system showed efficiency of COD degradation as $95.3 \pm 2.2 \%$ (with ozone treatment) and $78.6 \pm 4.5 \%$ without ozone treatment. The final concentration effluent for livestock wastewater was $167.7 \pm 62$ $\mathrm{mg} / \mathrm{L}$. Aerobic activated sludge with continuous system was conducted to test that result and it average efficiency only decreased into $85 \%$. This concentration was qualified to be discharged into environment.
\end{abstract}

Keywords: Activated sludge; anaerobic baffled reactor; livestock; ozone; wastewater

\section{Introduction}

Growing world population raise the demand livestock products [1]. The increasing of livestock wastewater in developing country due to high consumption of meat. Livestock wastewater majorly used as fertilizer, but it only degraded its organic matters. Whereas, its inorganic matters cannot be degraded properly and become residue that could threated environment especially water pollution like decreasing of water quality because of high nutrients. Livestock wastewater as organic waste that is consist of protein, carbohydrate, fat, mineral salt, can act as growth media and microbes breeding. Degradation process in wastewater makes the level of BOD, $\mathrm{COD}, \mathrm{NH}_{3}, \mathrm{H}_{2} \mathrm{~S}$ and $\mathrm{pH}$ changing and also raises bad odor like urea, Sulphur, and heavy metals. Heavy metals will affect leads to plant growth and heavy metals accumulation to plant [2, 3]. Besides that, the decreasing of DO level excessively can cause degradation of water quality. Generally, water body has capability to do self-purification, but with the increasing number of pollutants into water body caused autogenously purification of water body decrease. It is

*Corresponding author. +62-2277-4992

Jl. Teuku Nyak Arief, RT.7/RW.8, Simprug

Kec. Kebayoran Lama, Jakarta Selatan

Jakarta 12220 indicated with the changing of physical, chemical and biological in water body.

Anaerobic Baffled Reactor (ABR) is one of modification septic tank reactor with compartment addition [4]. ABR used to treat wastewater with high level COD like livestock wastewater. ABR treatment consists of compartments which are limited by vertical bulkhead growth with attached bacteria. Commonly, ABR consist of compartments that is arranged series. ABR combines sedimentation process with sludge decomposition partially in the same compartment, basically that compartment is sedimentation pond without moving parts or chemical materials adding. However, efficiency of COD degradation in ABR system still under $85 \%$ and yet qualified to standard quality $[5,6]$. Hence, advanced treatment needs to be conducted to increase treatment's efficiency [7]. This study conducted ozone treatment and aerated activated sludge as advance treatment.

Plasma discharge technique is one of technic to produces ozone gas $\left(\mathrm{O}_{3}\right)$ as strong oxidation that is effective in wastewater treatment. Ozone can increase biodegradability of wastewater. Ozone including into strong oxidant after Fluor (F), but safe and environmentally friendly, because in the end of reaction, 
Table 1. Characteristics of livestock wastewater effluent

\begin{tabular}{cccc}
\hline No & Parameters & Value & Unit \\
\hline 1 & $\mathrm{COD}$ & $9046 \pm 193$ & $\mathrm{mg} / \mathrm{L}$ \\
2 & $\mathrm{BOD}_{5}$ & $3479 \pm 58$ & $\mathrm{mg} / \mathrm{L}$ \\
3 & $\mathrm{TSS}$ & $1432 \pm 189$ & $\mathrm{mg} / \mathrm{L}$ \\
4 & $\mathrm{VSS}$ & $10575 \pm 227$ & $\mathrm{mg} / \mathrm{L}$ \\
5 & $\mathrm{NH}_{3}-\mathrm{N}$ & $34.7 \pm 0.7$ & $\mathrm{mg} / \mathrm{L}$ \\
6 & $\mathrm{TKN}$ & $2589 \pm 345$ & $\mathrm{mg} / \mathrm{L}$ \\
7 & $\mathrm{pH}$ & $7.6-8.2$ & \\
8 & $\mathrm{BOD} / \mathrm{COD}$ & 0.38 & \\
9 & $\mathrm{C} / \mathrm{N}$ & 4.02 & \\
\hline
\end{tabular}

ozone $\left(\mathrm{O}_{3}\right)$ reform into oxygen $\left(\mathrm{O}_{2}\right)$. Some studies stated ozone is a process which increased biological treatment's efficiency $[8,9,10]$. Moreover, ozone appropriate as posttreatment in ABR method [11].

Ozone process cannot degrade all of organic materials chemically, so off the treatment can further with aerobic activated sludge treatment. The combination of ABR and aerobic activated sludge treatment had applied and successes to increase efficiency of organic materials removal $[7,12,13]$. This method requires air supply and it can maintain a high microbe concentration to absorb and accelerate the removal of organic matter.

The fact that ABR method's result yet still qualified into quality standard of wastewater, make this method need to be improved. Advanced processing that is used is ozone, aerated activated sludge and combined ozone and activated sludge. The objective of this study was to evaluate the performance of an anaerobic baffled reactor (ABR) with post treatment ozone, aerated activated sludge, and combined ozone and activated sludge in the treatment of livestock wastewater.

\section{Materials and Methods}

\subsection{Livestock wastewater}

Livestock wastewater sourced from farm in Denpasar, Bali. COD level of that livestock wastewater after treatment was high, $9046 \pm 193 \mathrm{mg} / \mathrm{L}$, and was difficult to treat with aerobic process and also requires high power. Nowadays, those livestock wastewater only treated by ABR process and its effluent not fulfilling the quality standard. The main physic-chemical and biological characteristics of livestock wastewater used in this study are shown in Table 1.

\subsection{Reactor}

In the ABR, wastewater is flowed continuously from raw wastewater tank by HRT 6 in 12 hours. ABR has a volume of $25 \mathrm{~L}$ and also 3 baffle compartments (Fig. 1). Next, wastewater is flowed into ozone reactor with a capacity of $10 \mathrm{~L}$ in the batch system. Ozone generator that is used have doses $1200 \mathrm{mg}$ per hour. The procedure is continued by aerobic activated sludge with batch system and repeatedly. The aerobic system is classified into two, which are with ozone and without ozone.

\subsection{Analysis procedure}

The analysis parameters are $\mathrm{DO}, \mathrm{BOD}_{5}, \mathrm{COD}, \mathrm{pH}$, TKN and NH3-N established on standard method APHA AWWA. Essential parameter in this research is COD value that measured periodically. Each wastewater is retrieved as much as $20 \mathrm{~mL}$ from sampling port then analyzed based on each paramaters.

\section{Results and Discussion}

\subsection{ABR treatment}

The average characteristics of influent and effluent after the ABR treatment at 6 and $12 \mathrm{~h} \mathrm{HRTs}$ are summarized in Fig. 2. The average effluent COD values at $6 \mathrm{~h}$ HRT were found to be around $4489.7 \mathrm{mg} / \mathrm{L}$, respectively, while at $10 \mathrm{~h}$ HRT average COD values were of the order $4182 \mathrm{mg} / \mathrm{L}$, respectively. At both HRTs COD removal averaged $50-53 \%$ indicating poor amount of removal.

The result of ABR treatment similar to the result of anoxic treatment of piggery wastewater which produced COD removal for $54.5 \%$ for anoxic activated sludge and $51-60 \%$ for ABR $[14,15]$. As well as the result of $\mathrm{NH}_{3}-\mathrm{N}$, removal which merely produced $50-58 \%$ of value. This product is not complied the standard quality of wastewater of livestock industry.

The product of COD removal in process indicates low value compared to another research which produced more than $80 \%$ [16, 17]. The high removal fluctuation is produced by Pirsaheb et al.,with COD influent value of $15.000 \mathrm{mg} / \mathrm{L}$ by removal efficiency value of $43.01 \%$ and 95.13\% respectively [18]. This matter is probably happened in consequence of highly NH3-N concentration in the wastewater. Much as ammonia is the essential nutrition for bacteria's growth, but if it is highly concentrated, it also can hinder methanogenesis during aerobic digestion process [19]. The after-process measurement result indicates $\mathrm{COD} / \mathrm{BOD}$ value of $022 \pm 0.03$, which is this value reveals the low biodegradability.

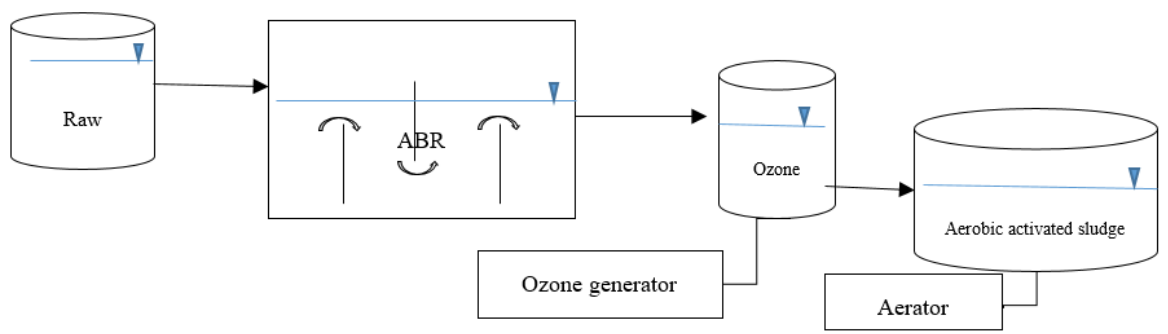

Figure 1. Flow chart of livestock wastewater treatment process 


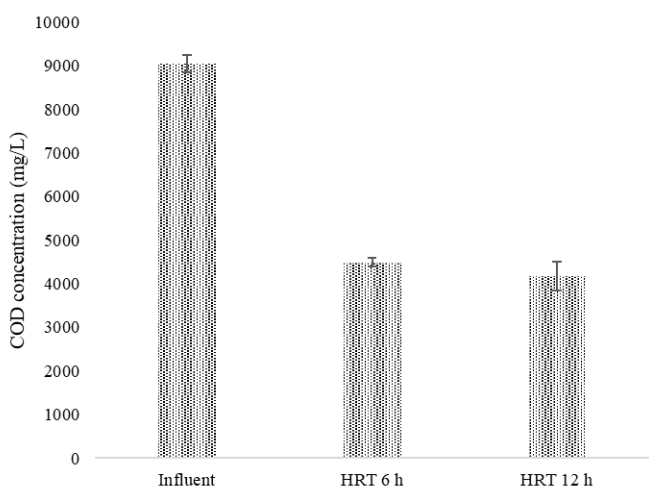

(a)

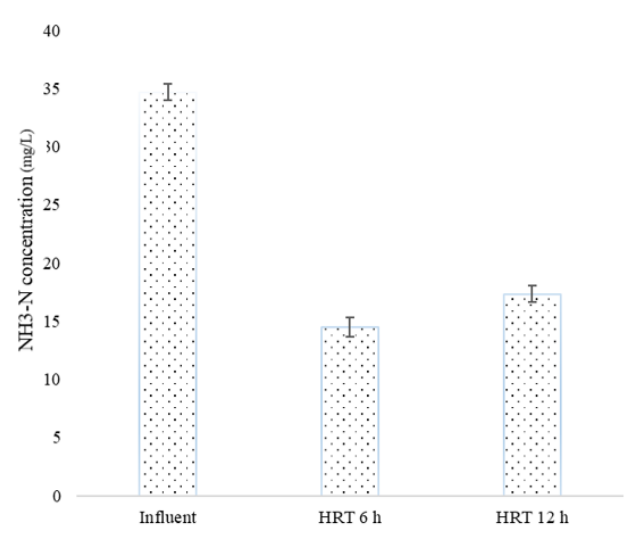

(b)

Figure 2. The results of livestock wastewater treatment with ABR tanks with different HRT (a) $\mathrm{COD}$ (b) $\mathrm{NH}_{3}-\mathrm{N}$

\subsection{Ozone treatment}

Indirect ozone reaction into $\mathrm{OH} \cdot$ radicals is dominantly functioning in the organic compound removal to produce higher quality of removal efficiency. This research stabilizes ozone mechanism is the method that can be used to remove organic material composition [8]. COD as organic removal (Fig. 3) and $\mathrm{NH}_{3}-\mathrm{N}$ as nutrient removal indicates the quite low value of $31.1 \pm 1.5 \%$ and 19.2.1 $\pm 2.1 \%$. The result of BOD measurement indicates no difference with the average efficiency of $1 \%$. There is a quite high increasing of BOD/COD value, from $0.25 \pm 0.02$ to $0.37 \pm 0.01$. Increasing the $\mathrm{BOD} / \mathrm{COD}$ value showed in Fig. 4.

Some other parameter which determines the effectively of ozone mechanism is BOD as organic material indicator that can be degraded biologically. Another research that used $\mathrm{UV} / \mathrm{H}_{2} \mathrm{O}_{2}$ oxidation process from effluent $\mathrm{ABR}$ increasing $\mathrm{BOD} / \mathrm{COD}$ ratio of 0.4 to 0.6 [17]. $\mathrm{NH}_{3}-\mathrm{N}$ also indicates poor effluent, which is $12.6 \pm 1.1 \mathrm{mg} / \mathrm{L}$ with efficiency value of $29.7 \pm 1.4 \%$. With reference to $\mathrm{pH}$ value in the ozone treatment, it indicates normal $\mathrm{pH}$ (7.2-7.5), where based on Khuntia et al., the optimum $\mathrm{pH}$ to be used in ammonia removal is up to 9 [19].

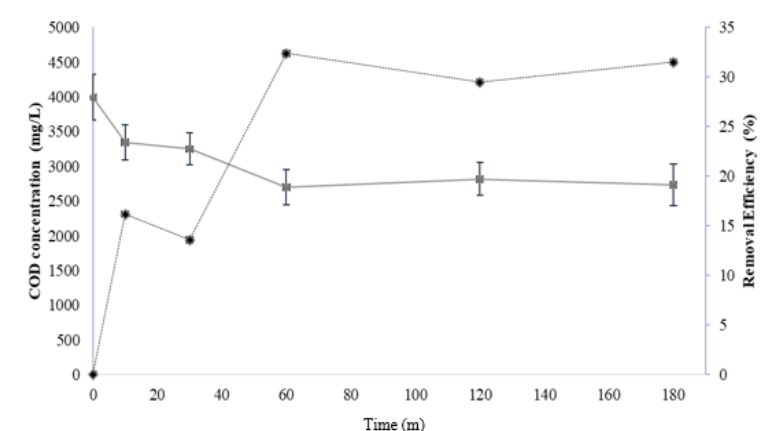

Figure 3. Degradation of COD as organic compounds with ozone pretreatment

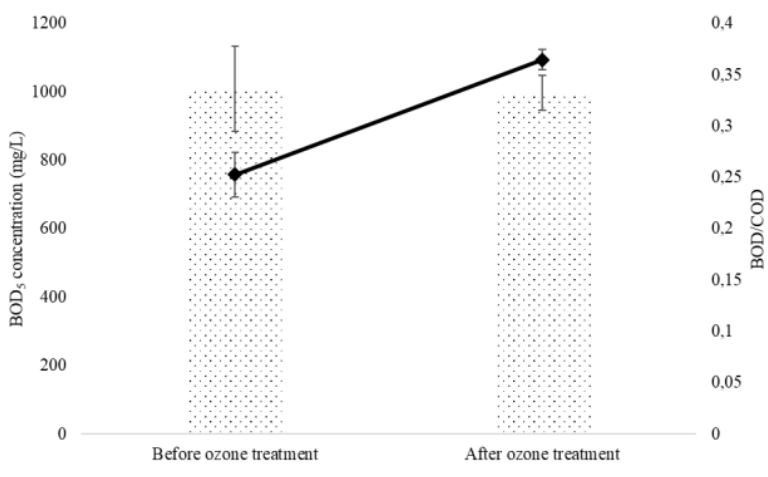

Figure 4. Changes in the value of BOD and biodegradability (BOD/COD) with ozone pre-treatment

\subsection{Aerobic activated sludge treatment}

In the aerobic activated sludge process, the used MLVSS concentration is about $831 \mathrm{mg} / \mathrm{L}$ at start-up. Which the sustained DO value is up to $4 \mathrm{mg} / \mathrm{L}$ to initiate the optimum aerobic processing [20]. The result can be viewed at the Fig. 5. COD removal efficiency with time detention of 60 days for $\mathrm{S} 2$ has reached the efficiency $95.3 \pm 2.2 \%$ with a value of $167.7 \pm 62 \mathrm{mg} / \mathrm{L}$. $\mathrm{NH}_{3}-\mathrm{N}$ removal only reached $52 \pm 6.2 \%$.
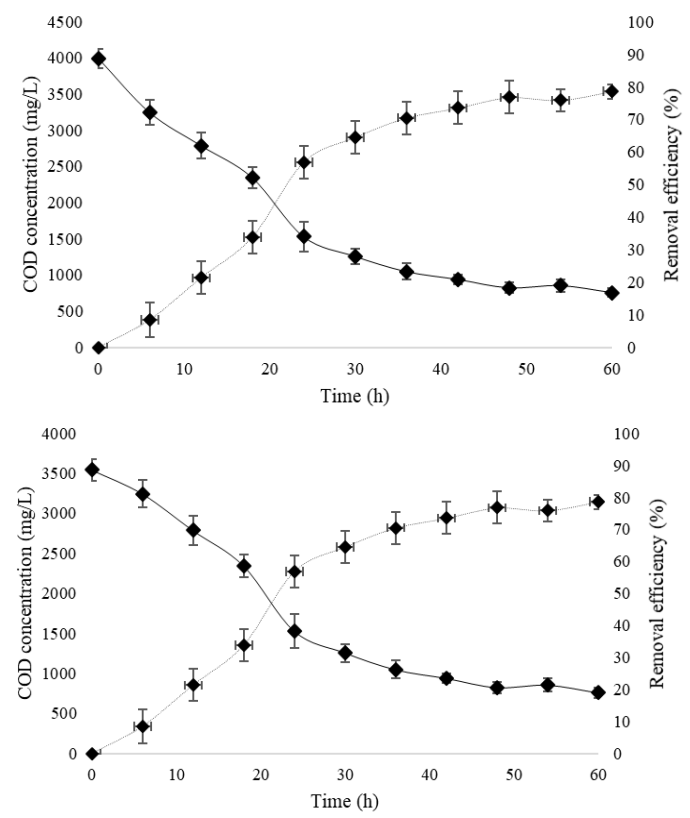

S2

Figure 5. Removal of COD values by active sludge treatment process ( $\mathrm{S} 1=$ without ozone pre-treatment and $\mathrm{S} 2=$ with ozone pre-treatment) 


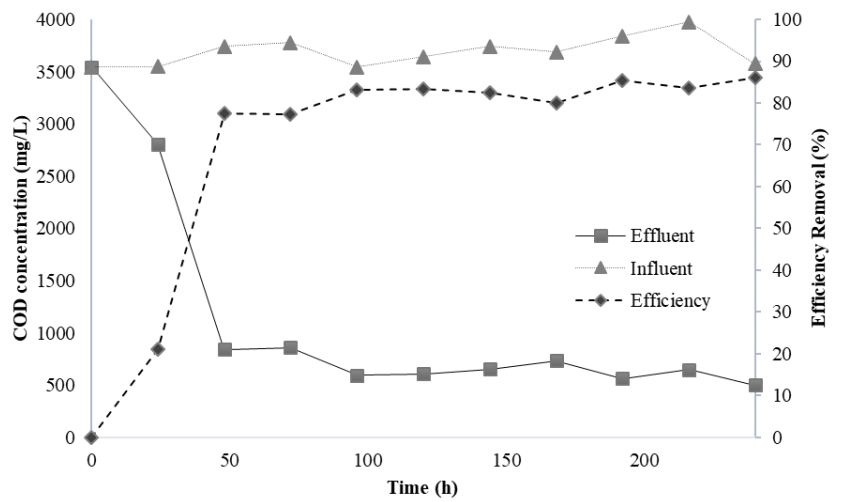

Figure 6. Removal of COD values by the active sludge treatment process in the continuous process with 48 hours HRT

In the meantime, the result of without-ozone process (S1) only produces $\mathrm{COD}$ and $\mathrm{NH}_{3}-\mathrm{N}$ efficiency of $78.6 \pm 4.5 \%$ and $41.2 \pm 7.1 \%$. Combined of activated sludge and ozone value have passed the threshold standard class in Indonesia. Next, the process output is tested by continually system with HRT 48 hours, which is the result reached the maximum COD efficiency $86 \%$ (Fig. 6) and $\mathrm{NH}_{3}-\mathrm{N}$ efficiency only $39 \%$.

This outcome of aerobic activated sludge treatment is established by another research which combined the ABR process with aerobic process that produces removal efficiencies $98 \%$ and $100 \%$ [21]. The result in continuous system is established by Pratiwi et al., statement, the further decrease of HRT [10], the COD removal declined apparently. Another research also stated the combined anaerobic/aerobic process with HRT 19.7 and 1.22 days producing COD removal about $97 \%$ and $91 \%$ [22].

As a result of that matter, it needs the adjustment of HRT value in the treatment process of livestock wastewater. To remove the suspended particles can use bio flocculants which non-toxic and more eco-friendly solution [23]. For nutrient removal like $\mathrm{NH}_{3}-\mathrm{N}$ can use phytoremediation or constructed wetland. Contracted wetland has ability to metabolize/absorb certain chemicals like $\mathrm{NH}_{3}-\mathrm{N}[2,24,25]$.

\section{Conclusions}

The result of COD removal with ABR system is quite low, which is $50-53 \%$. The results indicate that in the batch system, ozone can increase BOD/COD and decrease the COD only $31.1 \pm 1.5 \%$. Significant removal of COD in both reactors occurs at the first hour, but reactor with ozone treatment has higher removal efficiency of COD than without ozone treatment. The removal efficiency of COD in the both reactors was $95.3 \pm 2.2 \% \%$ and $78.6 \pm 4.5 \%$ respectively. In the continually process test (HRT $48 \mathrm{H}$ ) by ozone treatment, the COD removal maximum value is only $85 \%$.

\section{References}

[1] Belay, G., and Negesse, T. (2019). Livestock feed dry matter availability and utilization in burie zuria district, North Western Ethiopia. Tropical and Subtropical Agroecosystems, 22: 55-70.

[2] Apritama, M. R., Suryawan, I. W. K., Afifah, A. S., and Septiariva, I. Y., (2020). Phytoremediation of effluent textile WWTP for NH3$\mathrm{N}$ and $\mathrm{Cu}$ reduction using pistia stratiotes. Plant Archives, 20: 23842388 .
[3] Johanto, A., Rosariastuti, R., and Cahyani, V. R. (2019). Effort to get safe rice for consumption through bioremediation technology in paddy field contaminated by lead. Tropical and Subtropical Agroecosystems, 22: 179-188.

[4] Bachman, A., Bread, V.L., and McCarty, P. L. (1985). Performance Characteristic of the Anaerobic Baffle Reactor. Water Research, 19(1): 99-106.

[5] Dyan, M. O., Putra, G. P., Budiyono, Sumardiono, S., and Kusworo T. J. (2015). The effect of $\mathrm{pH}$ and operation mode for COD removal of slaughterhouse wastewater with Anaerobic Batch Reactor (ABR). Waste Technology, 3(1): 7-13.

[6] Jürgensen L., Ehimen E.A., Born J., Holm-Nielsen J. (2016). Twophase anaerobic digestion for biogas production from dairy effluent-CSTR and ABR in series. Proceedings of the 24th European Biomass Conference and Exhibition; insert date of conf.; place of conference, Publisher name, Place of publication, 16981702 .

[7] Bodík, I., Kratochvíl, K., Gašpariková, E., and Hutňan, M. (2003). Nitrogen removal in an anaerobic baffled filter reactor with aerobic post-treatment. Bioresource Technology, 86(1): 79-84.

[8] Suryawan, I. W. K., Prajati, G., Afifah, A. S., \& Apritama, M. R (2020). NH3-N and COD reduction in Endek (Balinese textile) wastewater by activated sludge under different DO condition with ozone pretreatment. Walailak Journal of Science and Technology (WJST).

[9] Chaiprapat, A., and Laklam, T. (2011). Enhancing digestion efficiency of POME in anaerobic sequencing batch reactor with ozonation pretreatment and cycle time reduction. Bioresource Technology, 102(5): 4061-4068.

[10]Pratiwi R., Notodarmojo S., and Helmy Q. (2018). Decolourization of remazol black-5 textile dyes using moving bed bio-film reactor. The 4th International Seminar on Sustainable Urban Development (ISoSUD); August 9-10, 2017; Jakarta, Indonesia. In IOP Conf. Series: Earth and Environmental Science 106: 1-6.

[11] Marchioretto M. M., and Reali M. A. (2001). Ozonation followed by coagulation/flocculation and flotation as post-treatment of the effluent from an anaerobic baffled reactor treating domestic sewage. Water Science and Technology, 43(8): 99-106.

[12]Da Silva, G. H. R., Sarti, A., Maintinguer, S. I., Kaiser I. M., and da Silva, G. H. R. (2017). Performance of an anaerobic baffled reactor with an aerobic chamber treating low-strength wastewater. insert short title of journal,insert, Volume number(issue number): insert number of page.

[13] Tanikawa, D., Yakote, N., Nakahara, K., and Yamaguchi, T. (2016). Evaluation of process performance for lipid-rich wastewater treatment using a combination system of an anaerobic baffled reactor and an aerobic trickling filter. Journal of Water and Environment Technology, 14, 90-95.

[14] Suryawan, I. W. K., Afifah, A. S., and Prajati G. (2019). Degradasi bahan organik dan pertumbuhan biomassa konsorsium pada air limbah olahan babi dengan lumpur aktif anoksik. Jurnal Teknik Kimia dan Lingkungan, 3: 20-26.

[15] Suryawan, I. W. K., Prajati, G., Afifah, A. S., Apritama, M. R., \& Adicita, Y. (2019). Continuous piggery wastewater treatment with anaerobic baffled reactor (ABR) by bio-activator effective microorganisms (EM4). Indonesian Journal of Urban and Environmental Technology, 3(1): 1-12.

[16] Aqaneghad, M., Moussavi, G., and Ghanbari, R. (2018). Anaerobic baffled reactor and hybrid anaerobic baffled reactor performances evaluation in municipal wastewater. Iranian Journal of Health, Safety and Environment, 5(3): 1027-1034.

[17]Cao, W., and Mehrvar, M. (2011). Slaughterhouse wastewater treatment by combined anaerobic baffled reactor and $\mathrm{UV} / \mathrm{H} 2 \mathrm{O} 2$ processes. Chemical Engineering Research and Design, 89(7): 11361143.

[18]Pirsaheb M., Rostamifar M., Mansouria, A. M., Zinatizadeh A. A L., and Sharafief K. (2015). Performance of an anaerobic baffled reactor (ABR) treating high strength baker's yeast manufacturing wastewater. Journal of the Taiwan Institute of Chemical Engineers, 47: $137-148$

[19] Khuntia, S., Majumder, S. K., and Ghosh, P. (2013). Removal of ammonia from water by ozone microbubbles. Industrial \& Engineering Chemistry Research, 52: 318-326.

[20]Djenar N. S., and Soeswanto B. (2005). Penyerapan polutan logam besi $(\mathrm{Fe})$ dengan memanfaatkan tanaman eceng gondok. Jurnal Fluida, 4(1): 35-40.

[21]Sponza D. T., and Demirden, P. (2010). Relationships between chemical oxygen demand (COD) components and toxicity in a sequential anaerobic baffled reactor/aerobic completely stirred 
reactor system treating Kemicetine. Journal of Hazardous Materials, 176(1-3): 64-75.

[22] Işık, M., \& Sponza, D. T. (2008). Anaerobic/aerobic treatment of a simulated textile wastewater. Separation and purification technology, 60(1), 64-72.

[23] Czemierska, M., Szcześ, A., and Jarosz-Wilkołazka, A. (2015). Purification of wastewater by natural flocculants. BioTechnologia, 4: $272-278$.
[24]Ziembińska-Buczyńsk, A., Wyszyńska, K., and Miksch, K. (2017). Detection and characteristics of sulfamethoxazole-resistant bacteria in constructed wetlands treating sulfamethoxazole-rich wastewater. BioTechnologia, 98 (1): 15-23

[25] Suryawan I. W. K., Helmy, Q., and Notodarmojo S. (2020) Laboratory scale ozone-based post-treatment from textile wastewater treatment plant effluent for water reuse. The 5th International Conference on Technology and Vocational Teachers; October 5-6, 2019, Yogyakarta, Indonesia. In Journal of Physics: Conference Series 1456: 1-8. 